\title{
SUHU DARI LUAR TANGKI MUATAN MEMPENGARUHI PROSES MEMUAT DI LPG / C. LADY HILDE
}

\author{
Bintang Dwi Prayogo ${ }^{a}$, Samsul Huda ${ }^{b}$ dan Tri Kismantoro ${ }^{c}$ \\ ${ }^{\mathrm{a}}$ Taruna (NIT.48114043.N) Program Studi Nautika PIP Semarang \\ ${ }^{b}$ dan Dosen Program Studi Nautika PIP Semarang
}

\begin{abstract}
ABSTRAK
Latar belakang penulisan penelitian ini karena dalam pengangkutan muatan gas sering ditemui beberapa kendala yang kemudian dirumuskan dalam beberapa permasalahan, adapun permasalahan yang ditemui antara lain bagaimana gambaran pengaruh suhu dari luar tangki muatan dalam proses memuat propane dan upaya apa saja yang harus dilakukan apabila suhu diluar tangki berbeda dengan suhu di dalam tangki muatan. Di dalam penelitian ini menggunakan metode kualitatif, yakni penelitian bertujuan untuk menjelaskan fenomena dengan sedalam-dalamnya melalui pengumpulan data. Penelitian ini tidak mengutamakan besarnya populasi atau sampling, bahkan sampling sangat terbatas. Jika data yang terkumpul sudah mendalam dan bisa menjelaskan fenomena yang diteliti, maka tidak perlu mencari sampling lainnya. Penelitian kualitatif lebih menekan pada persoalan kedalaman (kualitas) data, bukan banyaknya (kuantitas) data.Dapat disimpulkan bahwa perubahan suhu di luar kapal dapat sangat mempengaruhi kegiatan penanganan bongkar muat terutama pada saat berlangsungnya pemuatan, dimana pada saat suhu diluar sangat dingin ataupun panas dapat mempengaruhi kondisi muatan dan tangki.
\end{abstract}

Kata kunci: suhu, tangker, muatan gas

\section{ABSTRACT}

The background of the writing of this study because the freight is often encountered some obstacles gas which is then encapsulated in a few issues, while the problems encountered, among others, how is the role of the temperature outside propane tank in the loading process and any attempt to do when the temperature outside is different tanks with the temperature in the cargo tank. In this study using qualitative methods, the research aims to explain the phenomenon of the deepest data collection. This study does not give priority to population size or sampling, even a very limited sampling. If the data collected has been profound and could explain the phenomenon under study, then no need to look for other sampling. Qualitative research is more pressing on the issue of depth (quality) of data, not the number (quantity) of data.It can be concluded that the change in temperature outside the vessel can greatly affect the handling of loading and unloading activities, especially in the course of loading, at which time the temperature outside is very cold or heat can affect the condition of the cargo and the tank.

Keywords: temperature, tanker, gas cargo 
Bintang Dwi Prayogo, Samsul Huda dan Tri Kismantoro

\section{PENDAHULUAN}

Seiring dengan perkembangan teknologi yang semakin canggih, kapal sebagai alat transportasi di laut telah banyak mengalami kemajuan. Pada saat ini berbagai macam muatan telah dapat diangkut dengan menggunakan jasa kapal. Dari jenis kapal niaga yang mengangkut bermacam-macam muatan salah satunya adalah kapal Liquefied Petroleum Gas (LPG).

Kapal LPG merupakan jenis kapal niaga yang mengangkut muatan gas yang dicairkan. Kapal LPG dibagi menjadi beberapa jenis yaitu Fully Pressurised Ship, Semi Pressurised Ship, Fully Refrigerated Ship.

Setiap kapal gas telah dirancang untuk mengangkut muatan gas yang mempunyai karakteristik yang berbeda baik dalam penanganan muatan maupun sistem pengangkutannya. Dari daftar muatan berbahaya yang telah ditetapkan oleh International Maritime Organization (IMO) sebagai suatu organisasi internasional yang bergerak dalam bidang kemaritiman, muatan gas dikategorikan sebagai muatan yang sangat berbahaya. Ada beberapa jenis muatan gas yang sangat berbahaya antara lain Liquefied Natural Gas (LNG), Natural Gas Liquids (NGLs), Liquefied Petroleum Gas (LPG), Ammonia, Ethylene, Propylene, Butadiene, dan Vinyl Cloride. Dari daftar muatan gas yang telah disebutkan di atas ada satu jenis muatan gas yang sangat berbahaya tetapi tidak mudah terbakar yaitu Chlorine.

Alasan mengapa muatan gas dianggap sebagai muatan yang sangat berbahaya yaitu karena gas mempunyai sifat yang mudah meledak, terbakar, dan sangat beracun yang menjadikannya patut untuk diwaspadai demi keselamatan kapal, awak kapal, serta lingkungan di sekitar kapal.

Dengan melihat perlunya penanganan khusus dalam menangani muatan LPG, maka untuk pembuatan penelitian penulis merasa tertarik untuk memberikan sumbangan pengetahuan berdasarkan pengalaman penulis selama praktek laut di atas kapal LPG/C. LADY HILDE yang memuat propane dan butane dengan mengambil judul "Analisa pengaruh suhu dari luar tangki muatan terhadap proses memuat propane di LPG/C. LADY HILDE fully pressurized"'

\section{METODOLOGI PENELITIAN}

Kata metodologi berasal dari penggabungan dua kata yang berasal dari bahasa Yunani, yaitu Metodos dan Logos. Metodos berarti melaluidan logos berarti ilmu pengetahuan. Metode merupakan suatu kerangka kerja untuk melakukan suatu tindakan, atau suatu kerangka berfikir untuk menyusun suatu gagasan, yang beraturan, berarah dan berkonteks dengan maksud dan tujuan.

Research (Penelitian) ialah suatu kegiatan mengkaji secara teliti dan teratur dalam suatu bidang ilmu menurut kaedah tertentu. Sedangkan mengkaji ialah suatu usaha untuk memperoleh atau menambah pengetahuan. Jadi, meneliti dilakukan untuk memperkaya dan meningkatkan kepahaman tentang sesuatu.

Di dalam penelitian ini menggunakan metode kualitatif, yakni penelitian bertujuan untuk menjelaskan fenomena dengan sedalam-dalamnya melalui pengumpulan data. Penelitian ini tidak mengutamakan besarnya populasi atau sampling, bahkan samplingnya sangat terbatas. Jika data yang terkumpul sudah mendalam dan bisa menjelaskan fenomena yang diteliti, maka tidak perlu mencari sampling lainnya. Penelitian kualitatif lebih menekan pada persoalan kedalaman (kualitas) data, bukan banyaknya (kuantitas) data (Kriyantono, 2009:56). Dalam penulisan penelitian ini subjek yang penulis teliti adalah berbagai macam permasalahan yang dihadapi dalam proses pemuatan liquefied petroleum gas (LPG) di kapal LPG/C. LADY HILDE, tempatpenulis melaksanakan praktik laut selama 1 (satu) tahun.

Metodologi secara umum didefinisikan sebagai "a body of methods and rules 
followed in science or discipline". Sedangkan metode sendiri adalah "a regular systematic plan for or way of doing something". Kata metode berasal dari istilah Yunani methodos (meta+bodos) yang artinya cara. Jadi, metode penelitian adalah cara sistematik yang digunakan peneliti dalam pengumpulan data yang diperlukan dalam proses identifikasi dan penjelasan fenomena yang tengah ditelisiknya. Secara dikotomis dikenal dua jenis metode penelitian yaitu kuantitatif dan kualitatif. Sedangkan penelitian adalah suatu kegiatan pencarian, penyelidikan dan percobaan secara ilmiah dalam suatu bidang tertentu untuk mendapatkan fakta-fakta atau prinsip-prinsip baru yang bertujuan untuk mendapatkan pengertian baru dan menaikkan tingkat ilmu serta teknologi.

\section{Jenis/Tipe Penelitian}

Jenis penelitian bersifat deskriptif, yang bertujuan memberikan gambaran peranan suhu dari luar tangki dalam proses memuat propane serta dampak dan upaya sebagai bentuk penanganan. Penelitian ini menggunakan kapal yang sudah Taruna tempati untuk praktik laut sebagai objek penelitian, dimana peneliti terlibat langsung dalam proses pemuatan di kapal LPG/C. LADY HILDE.

Menurut Soesanto (2003:1)Penelitian ialah sebuah usaha untuk menjawab pertanyaan-pertanyaan yang timbul dan terumuskan dari dan dalam proses pengamatan atau pemikiran seseorang.

Menurut Bogdan dan Biklen, S.(1992:21-22) menjelaskan bahwa penelitian kualitatif adalah menghasilkan uraian data deskriptif berupa ucapan atau tulisan dan prilaku orang-orang yang diamati. Penelitian kualitatif bertujuan untuk memperjelas fenomena dengan mengumpulkkan data sedalamdalamnya, penelitian ini tidak memerlukan besarnya populasi atau sempel, melainkan menekankan pada suatu persoalan pada suatu persoalan kualitas bukan banyaknya atau kuantitas data.
Di dalam penulisan ini peneliti menggunakan penelitian deskriptif kualitatif. Fokusnya adalah penggambaran secara menyeluruh tentang bentuk dan fungsi.

Hal ini sejalan dengan pendapat Bogdan dan Taylor (1975) dalam Moleong (2002:3) yang menyatakan "metodologi kualitatif" sebagai prosedur penelitian yang menghasilkan data deskriptif berupa kata-kata tertulis atau lisan dari orang-orang atau perilaku yang dapat diamati. Dengan kata lain, penelitian ini disebut penelitian kualitatif karena merupakan penelitian yang tidak mengadakan perhitungan.

Penelitian kualitatif harus mempertimbangkan metodologi kualitatif itu sendiri. Metodologi kualitatif merupakan prosedur yang menghasilkan data deskriptif berupa data tertulis atau lisan di masyarakat bahasa Djajasudarma, (2006:11).

Lebih lanjut dijelaskan bahwa pendekatan kualitatif yang menggunakan data lisan suatu bahasa memerlukan informan. Pendekatan yang melibatkan masyarakat bahasa ini diarahkan pada latar dan individu yang bersangkutan secara holistik sebagai bagian dari satu kesatuan yang utuh. Oleh karena itu, dalam penelitian bahasa jumlah informan tidak ditentukan jumlahnya. Dengan kata lain, jumlah informannya ditentukan sesuai dengan keperluan penelitian.

\section{Subjek penelitian}

Dalam penulisan penelitian ini subjek yang penulis teliti adalah berbagai macam permasalahan yang dihadapi dalam proses pemuatan liquefied petroleum gas (LPG) di kapal LPG/C. LADY HILDE, dimana penulis telah melaksanakan proses pembelajaran semester lima dan enam atau praktik laut selama 1 (satu) tahun disana. Dan serta 
Bintang Dwi Prayogo, Samsul Huda dan Tri Kismantoro

berbagai Narasumber seperti Nahkoda, Mualim Satu, Mualim Dua, dan Mualim Tiga serta awak kapal lainnya yg berada di kapal LPG/C. LADY HILDE.

Untuk menunjang pengumpulan data serta agar mendapat tujuan yang diharapkan penulis memilih empat perwira di atas kapal sebagai data tertulis atau lisan dikarenakan beliau sudah berpengalaman dan mengetahui seluk beluk kapal serta tentang pemuatan liquefied petroleum gas (LPG) di kapal LPG/C. LADY HILDE.

\section{HASIL PENELITIAN DAN PEMBAHASAN}

Kegiatan muat yang benar dapat menjamin keselamatan anak buah kapal, kapal, muatan dan pelabuhan. Kesalahankesalahan harus dihindari guna mencegah bahaya yangdapat terjadi pada saat muat muatan Liquefied Petroleum Gas. Adapun hambatan yang dapat ditemui adalah:

> Gambaran pengaruh suhu dari luar tangki muatan dalam proses memuat propane

Dalam mengoperasikan kapal-kapal yang mengharuskan kita untuk selalu mengamati dan memperhatikan terhadap tekanan dan suhu dalam tangki muatmaka selain kita harus mengontrol suhu dan tekanan bawaan dari muatan itu sendiri kita juga tidak boleh melupakan faktor lain yang dapat juga mempengaruhi kenaikan suhu dan tekanan dalam tangki muat yaitu faktor panas dari lingkungan sekitar yaitu panas dari matahari atau bisa disebut juga ambient temperature.

Panas matahari tidak bisa kita abaikan begitu saja karena walaupun sadar atau tidak, panas matahari sangat mempengaruhi kenaikan suhu dan tekanan dalam tangki muat. Hal ini dapat terjadi karena sebagaimana yang kita ketahui, bila ada cairan dalam tabung tertutup yang dipanaskan maka suhunya akan naik yang diikuti dengan kenaikan tekanan dalam tabung tersebut juga.

Dari hasil wawancara dengan narasumber Nakhoda tentang bagaimana suhu muatan dan tekanan tangki bisa bertambah, dikatakan bahwa:

"Kenaikan suhu muatan dan tangki muatan bisa terjadi itu dikarenakan dua faktor. Faktor internal dan eksternal, faktor internal itu terjadi kenaikan karena sifat dasar muatan itu sendiri ada yang panas, ada yang dingin dan faktor eksternalnya adalah pengaruh suhu luar atau disebut ambient temperature dapat mempengaruhi suhu muatan itu sendiri dan cara pemuatan itu sendiri jika rate tinggi dapat sekali membuat suhu tinggi dan diikuti tekanan tangki yang meningkat."

Beberapa contoh yang dapat penulis berikan adalah sebagai berikut:

1. Fakta yang terjadi pada saat muat di Leixoes, Portugal

Pada saat proses loading berlangsung yaitu pada saat jam jaga Mualim II atau jaga tengah hari terjadi kenaikan tekanan dan suhu secara cepat sehingga mencapai tekanan di atas $10 \mathrm{~kg} / \mathrm{cm}^{2}$ dan temperatur melebihi $40^{\circ} \mathrm{C}$, hal ini terjadi karena pengaruh suhu musim panas atau summer time yang panas dan juga pemuatan yang dilakukan dengan rata-rata per jamnya yang terlalu besar yaitu mencapai 150 MT/jam sedangkan dalam kesempatan dengan loading master disepakati rata-rata per jamnya hanya 110-125 MT/jam sehingga terjadi pemampatan tekanan dalam tangki yang begitu cepat. Untuk itu maka harus dilakukan penurunan tekanan dan suhu yang dilakukan dengan cara menyemprotkan air laut ke atas tangki muat secara terus menerus dan merata, penyemprotan dilakukan melalui pipa-pipa cool down/sea water spray yang terletak di atas 
permukaan tangki yang air laut tersebut dipompa dengan menggunakan General Service Pump (GS pump). Proses ini dilakukan dengan terus menerus sampai suhu berangsur-angsur turun hingga mencapai derajat suhu yang diinginkan.

2. Fakta yang terjadi saat muat di Mongstad, Norway

Proses pemuatan di Norway yaitu pada saat jam jaga Mualim II saat siang hari. Berbeda dengan pada saat memuat di Leixoes Portugal. Proses pemuatan di Norway dilaksanakan pada saat musim dingin atau winter time proses pemuatan liquefied petroleum gas diterima kapal hanya satu macam yaitu propane. Perubahan suhu dan tekanan naik tidak terlalu besar karena sifat muatan ini yang dingin dan dilaksanakan pada saat musim dingin (winter time). Tetapi saat memasukkan muatan propane kedalam tangki muat kapal, terjadi kenaikan suhu dan tekanan yang wajar, hal ini disebabkan karena sifat muatan propane ini yang lebih panas dan rate yang tinggi.

Perubahan suhu di luar kapal sangat perlu diperhatikan oleh para perwira dan anak buah kapal dalam hubungannya dengan penanganan muatan khususnya saat melakukan proses pemuatan. Merujuk pada hukum Boyle, hukum Charles dan hukum tekanan yang menyatakan bahwa suhu mempunyai kaitan yang erat dengan volume dan tekanan. Semakin tinggi suhu maka tekanan juga akan ikut semakin bertambah demikian pula sebaliknya. Perubahan tekanan akan memberi dampak pada pelaksanaan kegiatan bongkar muat di atas kapal baik pada suhu di luar kapal yang tinggi ataupun dengan suhu yang rendah.

Serta

Menurut www.wisegeek.org/what-is-ambient- temperature dijelaskan bahwa ambient temperature memainkan peran utama dalam kenyamanan pribadi, serta fungsi dari berbagai jenis mesin dan peralatan, dan berbagai metode dapat digunakan untuk mengontrol suhu ruang. Biasanya, metode pengendalian dirancang untuk menjaga suhu stabil, karena fluktuasi suhu dapat menyebabkan ketidaknyamanan. Dalam arti suhu ruangan, suhu lingkungan dipengaruhi oleh sejumlah faktor, termasuk cuaca di luar, kualitas di ruang isolasi, apa atau siapa yang ada di dalam ruangan, dan penggunaan sistem pemanas dan pendingin.

Sifat-sifat dasar dari propane saat dimuat ke atas kapal

Dalam menangani pemuatan setiap jenis muatan hendaknya dilakukan dengan prosedural dan kehati-hatian yang tinggi, namun kebanyakan para awak kapal yang karena di atas kapal sudah tersedia alat-alat bantu operasional yang serba otomatis kadang-kadang menjadi lengah dan cenderung ceroboh serta mempercayai alat sepenuhnya. Entah mereka sadar atau tidak setiap alat pasti ada kelebihan dan kekurangan masing-masing, untuk itu agar setiap awak kapal bekerja dengan aman maka perlu diberikan prosedur atau check list sebagai acuan mereka, check list ini harus diisi setiap kali melakukan proses kegiatan bongkar maupun muat.

Di samping bekerja sesuai dengan prosedur hendaknya para perwira dan anak buah kapal mengetahui sifat-sifat dari muatan yang mereka muat sehingga bisa menjadikan mereka lebih berhatihati dalam melakukan proses pemuatan. Propane memiliki nama lain yaitu Methylethane, Methylethylene, dan Propylene. Propane memiliki sifat fisik yang tidak berwarna dan tidak berbau, berdasarkan ciri-ciri ini sering terjadi kelengahan para awak kapal dalam 
Bintang Dwi Prayogo, Samsul Huda dan Tri Kismantoro

menentukan ada tidaknya propane dalam suatu ruangan, bila seseorang terus menerus berada dalam suatu ruangan yang mengandung gas dalam jangka waktu lama dapat menyebabkan korban pusing, pingsan dan bila tidak segera ditolong dapat menyebabkan kematian pada korban.

Dalam keadaan darurat dibutuhkan prosedur untuk menanganinya yang terdiri dari:

1. Bila terjadi kebakaran

Kebakaran merupakan keadaan darurat yang dapat membahayakan keselamatan jiwa, kapal, muatan dan lingkungan disekitarnya. Prosedur yang dapat dilakukan bila terjadi kebakaran adalah:

a. Apabila terjadi kebakaran selama dalam proses pemuatan maka segera hentikan pemuatan.

b. Jangan padamkan kebakaran jika masih ada aliran gas atau vapour, hal ini dilakukan untuk menghindari kemungkinan terjadinya ledakan akibat menyalanya lagi muatan.

c. Alat pemadam yang digunakan hendaknya dry powder, atau karbon dioksida $\left(\mathrm{CO}_{2}\right)$.

d. Langkah terakhir yang harus dilakukan adalah mendinginkan tangki dan menyirami daerah sekitar kapal dengan sea water spray.

Yang merupakan sumber-sumber yang dapat menyebabkan kebakaran terhadap muatan adalah sebagai berikut:
a. Hot Work
Hot work atau pengelasan merupakan salah satu kerja yang harus dihindari dikerjakan di daerah tangki muatan selama ada muatan maupun sedang tidak ada muatan. Kerja panas dapat dilaksanakan ketika kapal berada di atas dock dengan ijin khusus dan tangki muatan di free gasatau atas seijin Mualim I atau nakhoda dengan mempertimbangkan risk assesment dan dilaksanakan sesuai prosedur.

b. Chipping

Kegiatan perawatan dengan menggunakan palu chipping hanya boleh dilakukan dengan palu chipping kuningan yang tidak dapat menimbulkan percikan bunga api.

c. Listrik statis

Pada saat pelaksanaan bongkar muat kemungkinkan terjadi loncatan listrik statis dapat menyebabkan kebakaran maka perlu dipasang grounding cable. Selain itu tidak boleh membawa telepon selular pada saat bongkar muat di cargo area.

2. Bila mata terkena cairan muatan

Mata sebagai salah satu indra yang terpenting bagi kehidupan manusia maka harus dirawat dengan baik dan apabila terjadi kecelakaan yang menimpa mata maka dapat dilakukan hal-hal di bawah ini:

a. Segera setelah mata terkena cairan muatan bilaslah mata dengan air tawar yang bersih sebanyakbanyaknya.

b. Usahakan mata tetap terbuka jika hal ini dapat dilaksanakan.

c. Ulangi pembilasan setidaknya selama 15 menit, dan segera minta saran atau bantuan medis secepat yang bisa dilakukan.

3. Bila kulit terkena cairan muatan

a. Jangan ditunda-tunda sesegera mungkin lepaskan pakaian korban yang terkontaminasi dan perlakukan korban dengan baik.

b. Sirami bagian yang terkena cairan atau yang terkontaminasi dengan air sebanyak mungkin dan lakukan terus-menerus setidaknya selama 15 menit.

c. Rendam atau basuh bagian yang yang terkena cairan muatan dalam 
air hangat, dan segera lakukan pertolongan medis sesegera mungkin.

4. Bila vapour terhirup

a. Bila ada korban yang menghirup vapour terlalu banyak maka segera pindahkan korban ketempat yang berudara segar dan segera lepaskan pakaian yang terkontaminasi.

b. Bila korban berhenti atau kesulitan bernafas berikan pertolongan pernafasan dengan teknik "mouth to mouth" atau dengan masker oksigen bila alat ini tersedia di atas kapal.

c. Segera beri pertolongan pertama dan minta bantuan medis secepatnya.

5. Bila terjadi kebocoran

a. Bila terjadi kebocoran muatan maka segera hentikan aliran, tetapi jangan sampai terjadi kontak dengan cairan ataupun vapour.

b. Banjiri dengan air yang banyak untuk melarutkan tumpahan dan untuk menghindari kerapuhan plat.

c. Alarm tanda bahaya dibunyikan dan informasikan ke pihak darat.

d. Semua pintu masuk dan lubang ventilasi ditutup, rokok, lampu minyak, dan kompor harus dimatikan dengan segera.

e. Informasikan kepada syahbandar tentang kebocoran muatan.

6. Bila Emergency Stop harus dilakukan

a. Gunakan Emergency Shutdown Discharge (ESD) yang berada di catwalk, poop deck sebelah kiri, dan panel cargo monitoring.

b. Kirim kabel emergency shut down tambahan ke darat.

c. Hubungi pihak darat dengan radio pada frekuensi yang telah ditentukan.

\section{Data-data fisik propane}

Bahaya-bahaya dari muatan seperti tingkat nyala api, berat jenis gas, tingkat racun dan lain-lain harus ditetapkan dan
Material Safety Data Sheet (MSDS) yang tertera dalam poster harus tersedia juga, dan hal ini harus diikuti dengan perhatian yang khusus.

a. Titik didih dan beku

Propane memiliki titik didih pada tekanan atmosphere sebesar $-47^{\circ} \mathrm{C}$ serta titik beku pada $-185^{\circ} \mathrm{C}$, pada suhu itu tekanan vapour berkisar 1.1 barg.

b. Bahaya ledakan

Bahaya ledakan dapat ditimbulkan oleh vapour yang bercampur dengan udara yang tersulut oleh percikan api, jika hal itu terjadi dapat mengakibatkan terlepasnya kekuatan ledakan yang dapat mengakibatkan kerusakan struktur atau bangunan kapal. Kebakaran dapat terjadi setelah ada konsentrasi 2-12\% dari volume propane di udara.

c. Kondisi pemuatan

Dalam kondisi pemuatan normal propene diangkut dalam pressurized tank atau fully refrigerated tank. Dalam pemuatannya tidak memerlukan tangki independent. Yang harus diperhatikan adalah bahaya kebakaran dari vapour. Penyondingan dilakukan dalam kondisi tertutup dan kedap.

d. Reaksi muatan

Propane tidak dapat larut dalam air, baik air tawar maupun air laut. Tetapi biarpun begitu bila tercampur dengan air tidak menimbulkan reaksi yang berbahaya. Hal yang sama juga berlaku bila propane bercampur dengan udara maka tidak akan menimbulkan reaksi berbahaya, reaksi berbahaya baru terjadi bila propane bercampur dengan chlorine.

Mengetahui sifat-sifat, bahaya-bahaya serta cara menangani masalah-masalah yang dapat terjadi dalam keadaan darurat saat pelaksanaan kegiatan pemuatan akan sangat berpengaruh kepada perwira dan para anak buah kapal dalam 
Bintang Dwi Prayogo, Samsul Huda dan Tri Kismantoro

melaksanakan tugas dan kewajibannya. Yang harus diingat oleh siapa saja yang bekerja yang berhubungan dengan bahan-bahan yang berbahaya adalah bahwa setiap saat, setiap tempat dan kepada siapa saja bahaya dapat mengancam, baik itu bawahan maupun atasan.

Untuk menunjang kutipan di atas menurut Air gas MSDS (Material Safety Data Sheet) Propana adalah tidak berwarna, cair, gas yang mudah terbakar, dengan bau samar di tinggi konsentrasi. Gas cair dengan cepat berubah menjadi gas pada tekanan atmosfer standar dan suhu. Propanaadalah menyebabkan keadaan sesak nafas dan menyajikan bahaya kesehatan yang signifikan dengan menggusur oksigen di atmosfer. Kedua cairan dan gas menimbulkan bahaya kebakaran serius ketika sengaja dirilis. Gas lebih berat daripada udara dan bisa merebak panjang jarak. Pengapian jauh dan kilas balik yang mungkin. Kontak dengan gas berkembang cair atau cepat dapat menyebabkan radang dingin. Api atau suhu tinggi menimpa area lokal dari silinder Propana dapat menyebabkan silinder untuk pecah tanpa mengaktifkan perangkat bantuan silinder itu. Memberikan proteksi kebakaran yang memadai pada saat tanggap darurat.

Hal-hal yang dapat dilakukan untuk lebih mengenalkan karakteristik muatan kepada setiap awak kapal dapat dilakukan dengan jalan:

1. Sebelum awak kapal bekerja di atas kapal sebaiknya diberikan pelatihan yang cukup. Pelatihan ini dapat dilakukan ditempat-tempat pelatihan seperti lembaga pendidikan pelayaran maupun dilakukan sendiri oleh perusahaan yang bersangkutan.

2. Mengadakan safety meeting di atas kapal yang dipimpin oleh Nakhoda dan diikuti oleh seluruh awak kapal, terutama yang baru naik dan yang sedang tidak jaga untuk memberikan penjelasan tentang sifat, cara menangani dan resiko-resiko yang dapat terjadi terhadap muatanmuatan yang akan dimuat, dengan demikian awak kapal akan lebih mengenal dan waspada terhadap muatan yang mereka muat.

Upaya apa saja yang harus dilakukan apabila suhu di luar tangki berbeda dengan suhu dalam tangki muatan

Tindakan penanggulangan sangatlah penting digunakan jika suatu masalah terjadi. Maka penting juga untuk kapal LPG (liquefied petroleum gas) jika suatu saat di atas kapal saat proses bongkar atau muat lalu terjadi penurunan suhu dan kenaikan suhu. Maka perlunya sebuah tindakan penanggulangan agar tidak terjadi suatau keadaan yang dapat membahayakan awak kapal dan kapal itu sendiri.

Awak kapal diwajibkan untuk mengetahui dan memahami sistem metode yang sudah ada dan sudah sesuai dengan aturan yang sudah dibuat terutama bagi awak kapal yang mengangkut liquifed petrolium gas. Tindakan yang dapat dilakukan dapat membantu saat muatan kapal liquefied petroleum gas sedang mengalami kenaikan atau penurunan jika dilakukan sesuai prosedur yang ada.

Dari hasil wawancara dengan narasumber Nakhoda tentang cara penanggulangan jika terjadi kenaikan suhu atau tekanan tangki, dikatakan bahwa:

"Pada dasarnya jika suhu naik maka kita harus bisa melakukan penurunan suhu agar tekanan tangki pun ikut berkurang maka ada beberapa cara salah satunya dengan cara colling down yaitu dengan menyemprotkan air laut melalui pompa lalu dialirkan ke sea water spray, disemprotkan menyeluruh ke atas tangki muatan. Ada lagi menggunakan sirkulasi yaitu dengan mengambil vapour yang 
ada dalam tangki diambil melalui kompressor lalu dialirkan lagi ke dalam tangki. Itu sangat bahaya sekali jika awak kapal tidak dapat menanggulanginya maka dampak yang didapat bisa ledakan dan merusak tangki serta pipa muatan."

Untuk menangani permasalahan yang berhubungan dengan suhu dari luar kapal yang mempengaruhi suhu dalam tangki muat maka di atas kapal dilakukan tindakan-tindakan sebagai berikut:

a. Dampak apa saja yang terjadi, serta bagaimana penanganan saat suhu terlalu tinggi dan rendah:

Adapun dampak-dampak yang dapat terjadi dalam tangki muatan antara lain:

1) Dampak pada suhu yang terlalu tinggi yang sampai melebihi $40{ }^{\circ} \mathrm{C}$.

a) Suhu yang tinggi menyebabkan suhu dalam tangki meningkat, dimana suhu yang semakin tinggi akan menyebabkan meningkatnya tekanan dalam tangki.

b) Kemungkinan terjadi ledakan apabila suhu telah melebihi dari critical temperature yang dimiliki oleh muatan.

c) Terjadinya back pressure yang dikarenakan semakin tingginya suhu maka akan semakin tinggi tekanan yang mungkin dapat melebihi kapasitas aman pipa dan tangki muatan.

2) Tindakan penanganan saja yang dilakukan pada saat suhu terlalu tinggi adalah:

\section{a) Cool down}

Dilakukan agar tidak terjadi tegangan pada tangki karena adanya perbedaan suhu. Cool down dilakukan dengan cara menyemprotkan air laut secara terus menerus dan merata ke atas tangki muatan melalui pipa-pipa yang terletak di atas permukaan tangki muatan, dimana air laut akibat adanya gesekan antara muatan cair dengan pipa muatan dan antara muatan uap dengan pipa muatan, maka secara tidak langsung akan mengakibatkan kenaikan suhu terhadap muatan itu sendiri, tetapi yang lebih penting adalah karena pengaruh cuaca yang panas selama pemuatan atau selama pelayaran menuju pelabuhan bongkar yang mengakibatkan kenaikan suhu tangki dan tekanan pada tangki muatan. Untuk menurunkannya dengan mengalirkan atau menyiramkan air laut diatas dome tangki selama proses pemuatan atau selama pelayaran bila tekanan tangki naik maupun suhu didalam tangki naik, maka dengan mengalirkan air secara perlahan suhu dari tangki muatan akan turun secara induksi dan karena suhu berbanding lurus terhadap tekanan, maka tekanan dari tangki muatan akan turun pula dipompa dengan menggunakan General Service Pump (GS pump). Cool down ini dilakukan terus menerus sampai suhu berangsur-angsur turun hingga mencapai derajat suhu yang diinginkan.

\section{b) Chilling}

Proses ini dapat dilakukan bersama-sama dengan proses cool down yang mempunyai fungsi yang sama juga yaitu mendinginkan muatan untuk mengurangi kenaikan tekanan muatan. Pada dasarnya di dalam tangki terdapat alat pengukur suhu yang dibagi menjadi tiga yaitu bottom (bawah), midlle 
Bintang Dwi Prayogo, Samsul Huda dan Tri Kismantoro

(tengah), dan top (atas), jadi pada saat pemuatan muatan cair akan mengisi bagian bottom kemudian midlle dan sampai mengisi bagian top. Prinsip kerja cargo sprayline berbeda dengan sea water spray, yang berbeda adalah menggunakan muatan itu sendiri untuk mendinginkan vapour yang hangat dari dalam tangki bagian atas, muatan cair dari darat dialirkan melalui saluran dropline (pipa utama yang mengalirkan muatan cair) tetapi sebagian dari muatan tersebut dilewatkan melalui saluran ini. Secara logika didalam tangki terdapat dua jenis muatan yaitu muatan cair (liquid) berada dibawah dan uap muatan (vapour) dari muatan itu sendiri berada di atas, sehingga yang menjadi penyebab naiknya suhu dan tekanan adalah uap dari muatan tersebut yang hangat, maka penggunaan cargo sprayline untuk mendinginkan uap dari muatan dengan bentuk semprotan yang menyebar, karena muatan cair yang dingin ketika muat dari manifold kemudian ke drop linedan dialirkan sebagian pada cargo sprayline, melalui cargo sprayline semprotkan liquid dibagian atas berbentuk kabut dan menyebar pada bagian atas di dalam tangki, maka muatan cair akan bergesekan dengan muatan uap, maka uap (vapour) akan menjadi cair karena didinginkan oleh muatancair, dan yang perlu diketahui bahwa suhujuga tidak boleh kurang dari $0^{0} \mathrm{C}$ karena suhu kerja untuk kapal LPG/C. LADY HILDE ini adalah $0^{0} \mathrm{Csampai}$ $45^{\circ} \mathrm{C}$. c) Dengan menggunakan compressor

Prinsip kerja proses ini adalah menghisap vapour dari dalam tangki muatan yang panas, kemudian disalurkan kedalam kondensor yang berfungsi mendinginkan vapour untuk kemudian akan dimasukkan lagi ke dalam tangki muatan dan akan menurunkan tekanan secara perlahan.

Cara menggunakan kompresor bervariasi dalam menurunkan tekanan dalam tangki karena dari Mualim I mempunyai cara yang berbedabeda. Dikapal LPG/C. LADY HILDE kompresor muatan biasanya digunakan untuk mendorong muatan gas agar tekanan turun, dengan mensirkulasi muatan yaitu dengan menghisap muatan gas dari tangki yang dimuat dan didorong ke dalam tangki yang belum dimuat melalui saluran muatan uap atau sebaliknya, tangki yang bermuatan uap itu kembali dibuka dan didorong dengan kompresor ke dalam tangki yang sudah dimuat tetapi dengan membuka byepass jadi muatan cair bercampur dengan muatan uap, karena muatan cair dingin bercampur dengan muatan uap maka muatan uap pun akan menjadi cair.

3) Dampak yang terjadi bila suhu sampai mendekati atau dibawah $0^{\circ} \mathrm{C}$.

a) Apabila liquid tumpah ke atas deck dikhawatirkan akan terjadi brittle pada lantai deck yang dapat merusak plat/permukaan deck. 
b) Suhu di bawah $0^{\circ} \mathrm{C}$ akan mempengaruhi proses bongkar maupun muat karena secara otomatis tekanan akan menurun sedangkan kapal LPG diharuskan supaya menjaga tekanan muatan tetap positif.

4) Tindakan yang dilakukan apabila suhu terlalu rendah adalah:

a) Selama bongkar menghisap sisasisa vapour yang ada di dalam tangki dengan compressor tanpa melalui kondensor dari dalam tangki yang untuk kemudian dimasukkan lagi ke dalam tangki muatan. Dimana sirkulasi yang dilakukan compressor akan menghasilkan vapour dengan suhu yang lebih tinggi yang akan menambah tekanan vapour di dalam tangki muat.

b) Membuat sirkulasi muatan melalui reheater yang dipanaskan dengan air laut dari dalam tangki untuk kemudian dimasukkan kembali kedalam tangki muatan. Dimana liquid dari reheater yang masuk kedalam tangki akan sedikit demi sedikit memuai dan menambah tekanan dalam tangki. Dalam penelitian yang dilakukan di kapal LPG/C. LADY HILDE ternyata ditemukan kekurangan dimana tidak terdapat prosedur tertempel untuk menangani kejadian tersebut di atas, Cargo reheater hanya dapat digunakan untuk proses bongkar saja, dan tindakan yang dilakukan hanya berdasar pengalaman mualim satu dan bimbingan Nakhoda.

Dampak yang terjadi bila suhu muatan naik atau turun sangat perlu sekali dipahami agar awak kapal dapat siaga jika masalah itu timbul di luar rencana. Jika awak kapal tidak cepat menanggulanginya efek yang ditimbulkan bisa membahayakan awak kapal, kapal dan pelabuhan itu sendiri. Dengan pahamnya awak kapal tentang akibat yang ditimbulkan dari kenaikan suhu dan penurunan suhu maka kejadian-kejadian yang tidak kita inginkan dapat kita hindari.

Sedangkan menurut ISGINTT (International Safety Guide for Inland Navigation Tank-barges and Terminals) Ketika membawa muatan pada suhu rendah:

1) Jika disediakan pengaturan pemanas terkait dengan sistem penahan muatan harus dioperasikan sedemikian rupa untuk menghindari suhu jatuh di bawah suhu yang dirancang dari struktur dan material lambung.

2) Pemuatan harus dilakukan sedemikian rupa untuk memastikan bahwa perbedaan suhu yang tidak memuaskan tidak terjadi dalam tangki muatan, pipa, atau peralatan pendukung lainnya.

3) Bila pendinginan tangki dari suhu pada atau dekat suhu lingkungan, prosedur pendinginan yang ditetapkan untuk tangki tertentu, pipa dan peralatan tambahan harus diikuti.

Adapun prosedur untuk penanganan jika terjadi kenaikan suhu dan tekanan :

Penanganan bongkar muat di kapal LPG/C. LADY HILDE dapat dilihat pada lembar lampiran cargo document (loading cargo operation plan dan cargo operation instruction). Dalam melaksanakan bongkar muat diharapkan setiap perwira dan awak kapal memahami proses mulainya tahap-tahap pemuatandan mengerti alat-alat yang digunakan dalam kegiatan bongkar muat, maka inilah tahapan pemuatan di kapal liquefied petroleum gas agar proses memuat berjalan dengan lancar dan dapat meminimalkan terjadinya kenaikan suhu 
Bintang Dwi Prayogo, Samsul Huda dan Tri Kismantoro

yang dapat membahayakan bagi awak kapal dan kapal itu sendiri:

1. Perencanaan operasi

Sebelum melaksanakan kegiatan muat biasanya diadakan SafetyMeeting yang dilaksanakan oleh: Master, Chief officer, Second officer, Third officer, Bosun, ChiefEngineer, Second engineer, Third engineer, Fourth engineer, untuk membahas mengenai perencanaan pemuatan mulai sebelum memuat hingga sesudah memuat dan juga berhubungan dengan safety and security.

\section{Line Cooldown}

Lima jam sebelum tiba di pelabuhan muat, tanki muatan harus didinginkan (cooldown)supaya tanki muat siap untuk dimuati dengan cara melaksanakan penyemprotan menyeluruh ke tangki muatan menggunakan air laut.

3. Kapal sandar dan terikat

Setelah kapal sandar dan terikat selanjutnya yang dilakukan adalah menyiapkan gang way (tangga), menyiapkan alat pemadam seperti portable dry powder, chemical suit, menyalakan safety relieve valve dan siapkan alat komunikasi.

4. Loading Arm Connection

Setelah manifold kapal dihubungkan dengan lengan muat terminal darat kemudian yang dilakukan adalah: mengecek apakah ada kebocoran atau tidak (leak test). Kemudian setelah penyambungan lengan muat harus dilakukan purging untuk pipa darat dengan menggunakan $\mathrm{N} 2$ (Nitrogen) untuk menghilangkan campuran muatan lain.

5. Line Up (pengaturan pipa)

Mualim $M$ dan Mualim jaga melakukan line $U p$ sedangkan $A B$ (able seamen) mengecek dan meyakinkan bahwa pipa telah bekerja dengan benar. Pipa pada Loading valves pada masing-masing tangki, serta melihat tekanan tangki sudah mencapai berapa.

6. Start Loading (mulai pemuatan)

Setelah semua dalam keadan siap maka dapat dimulai transfer muatan dengan rate yang rendah sesuai batas maksimum yang sudah ada, dan melakukan cooldown dan sirkulasi jika dibutuhkan.

7. Finish Loading (selesai memuat)

Setelah pemuatan telah sesuai dengan hasil meeting maka lakukan topping off, diantaranya matikan compressor dan cooling line, pemberitahuan ke darat 1 jam atau 30 menit dan 15 menit atau 10 menit notice untuk ratedown.

8. Loading Arm Disconnection (pelepasan lengan muat)

Pelepasan loading arm (lengan muat) merupakan tanda bahwa pemuatan telah selesai yang diawali dengan pelepasan lengan muat cargo dan kemudian disusul dengan lengan muat vapour di manifold jika digunakan.

Penanganan permasalahan yang berhubungan dengan suhu dari luar kapal yang mempengaruhi suhu dalam tangki muat sangatlah perlu disaat melakukan proses pemuatan. Dampak yang diakibatkan/timbul karena perubahan suhu dapat diminimalkan pada saat suhu terlalu tinggi maka tindakan yang dilakukan adalah dengan menggunakan metode cool down dan chilling, hal ini sesuai dengan International Gas Carrier Code dan dilakukan sirkulasi vapour melalui compressor. Pada saat suhu terlalu rendah dapat diminimalkan dengan melakukan sirkulasi muatan dengan melalui reheater atau membuat sirkulasi vapour dengan melalui compressor tetapi tanpa melalui kondensor. Prosedurnya penanganan ini diperuntuhkan bagi OOW (officer on watch) jika kejadian kenaikan dan penurunan suhu terjadi. 
1) Cooldown

a. Untuk perwira jaga pastikan suhu muatan akan mencapai $40^{\circ} \mathrm{C}$

b. Catat dalam buku catatan bongkar muat meliputi pukul berapa kejadian terjadi.

c. Mulai order cooldown ke kamar mesin.

d. Pastikan cooldown line sudah siap untuk dipakai.

e. Monitor terus suhu muatan tersebut tiap jamnya.

f. Jika suhu sampai critical temperature, segeralah menghubungi Mualim I, lakukan sesuai emergency procedure high pressure.

2) Chilling

a. Untuk perwira jaga pastikan suhu muatan akan mencapai $40^{\circ} \mathrm{C}$.

b. Catat dalam buku catatan bongkar muat meliputi pukul berapa kejadian itu terjadi.

c. Buka valve chilling yang berada didekat sliptube .

d. Monitor terus tekanan tangki tersebut tiap jamnya.

e. Jika tekanan tangki semakin tinggi, segeralah menghubungi Mualim 1, kegiatan chilling dapat dilakukan beriringan dengan cool down.

3) Menggunakan compressor

a. Untuk perwira jaga pastikan tekanan tangki akan mencapai 5.0 $\mathrm{kg} / \mathrm{m}^{2}$

b. Catat dalm buku catatan bongkar muat meliputi pukul berapa kejadian terjadi.

c. Mulai order compressor book ke kamar mesin

d. Pastikan pipa pendingin compressor sudah dibuka dan air sudah mengalir.

e. Pastikan vapour line siap untuk digunakan.

Jika suhu dan tekanan di atas dari $40^{\circ} \mathrm{C}$ dan $5 \mathrm{~kg} / \mathrm{m}^{2}$ maka lakukan emergency prosedure yang sudah tertera dalam emergency procedure high pressure, agar suhu dan tekanan kembali ke titik aman di bawah $40^{\circ} \mathrm{C}$ dan $5 \mathrm{~kg} / \mathrm{m}^{2}$.

Perawatan yang dilakukan bagi alat bongkar muat:

Lancarnya operasi kapal, tentunya tidak lepas dari perencanaan dan penerapan perawatan kapal $(\mathrm{PMS}=$ Plan Maintenance System) serta koordinasi yang baik antara pihak perusahaan dengan pihak kapal. Akan tetapi perawatan setiap kapal dan tiap perusahaan berbeda-beda, demikian pula dengan kapal gas dikarenakan kapal gas sangat rentan akan bahaya kebakaran maka dari itu dilarangnya chiping dan pengelasan di atas deck. Ada pun jenisjenis perawatan sebagai berikut:

1. Perawatan preventif

Adalah pekerjaan perawatan yang bertujuan untuk mencegah terjadinya kerusakan, atau cara perawatan yang direncanakan untuk pencegahan.

Ruang lingkup pekerjaannya termasuk: pemeriksaan, perbaikan kecil, pelumasan atau penyetelan, sehingga peralatan atau mesin-mesin selama beroperasi terhindar dari kerusakan.

2. Perawatan korektif

Adalah pekerjaan perawatan yang dilakukan untuk memperbaiki dan meningkatkan kondisi peralatan sehingga mencapai standar yang dapat diterima. Dalam perbaikan dapat dilakukan peningkatan-peningkatan sedemikian rupa, seperti melakukan perubahan atau modifikasi rancangan agar peralatan menjadi lebih baik.

3. Perawatan berjalan

Dimana pekerjaaan perawatan dilakukan ketika fasilitas atau peralatan dalam keadaan bekerja. Perawatan berjalan diterapkan pada peralatan-peralatan yang harus beroperasi terus dalam melayani proses produksi. 
Bintang Dwi Prayogo, Samsul Huda dan Tri Kismantoro

4. Perawatan prediktif

Perawatan prediktif ini dilakukan untuk mengetahui terjadinya perubahan atau kelainan dalam kondisi fisik maupun fungsi dari sistem peralatan. Biasanya perawatan prediktif ini dilakukan dengan bantuan panca indra atau alat monitor yang canggih.

5. Perawatan setelah terjadi kerusakan (break down maintenance)

Pekerjaan perawatan dilakukan setelah terjadi kerusakan pada peralatan, dan untuk memperbaikinya harus disiapkan suku cadang, material, alat-alat dan tenaga kerjanya.

6. Perawatan darurat (emergency maintenance)

Adalah pekerjaan perbaikan yang harus segera dilakukan karena terjadi kemacetan atau kerusakan yang tidak terduga.

Di samping jenis-jenis perawatan di atas terdapat juga jenis pekerjaan lain yang bisa dianggap merupakan jenis pekerjaan perawatan seperti ini:

1. Perawatan dengan cara penggantian (replacement instead of maintenance)

Perawatan ini dilakukan dengan cara mengganti peralatan tanpa dilakukan perawatan, karena harga peralatan pengganti lebih murah bila dibandingkan dengan biaya perawatannya. Atau alasan lainnya adalah apabila perkembangan teknologi sangat cepat, peralatan tidak dirancang untuk waktu yang lama, atau banyak komponen rusak tidak memungkinkan lagi diperbaiki.

2. Penggantian yang direncanakan (planned replacement)

Dengan telah ditentukan waktu mengganti peralatan dengan peralatan baru, berarti tidak memerlukan waktu lama untuk melakukan perawatan, kecuali unuk melakukan perawatan dasar yang ringan seperti pelumasan dan penyetelan. Ketika peralatan telah menurun kondisinya langsung diganti dengan yang baru.

Perawatan alat bongkar muat di kapal LPG (liquefied petrolium gas) dapat dilakukan pada saat perawatan rutin yang hanya dikhususkan untuk merawat dan mengganti sedangkan jika ada yang perlu menggunakan pengelasan dan chipping maka harus dilakukan saat kapal docking atau saat kapal sedang berlayar atas seijin Mualim satu dan Nahkoda. Ini adalah beberapa alat bongkar muat yang digunakan di kapal LPG (liquefied petrolium gas) serta bagaimana cara pengecekan dan perawatan:

1. Cargo Pump

a) Periksalah pompa apakah ada karat yang berlebihan atau kerusakan mekanis, pompa harus bebas dari retak yang berlebihan, baut pelat dasar di tempat yang benar dan mengikat pompa.

b) Saringan dalam kondisi kerja yang baik dan bebas dari kebocoran.

c) Periksa pipa dan alat kelengkapan menggunakan detektor gas dikalibrasi atau pengujian kebocoran menggunakan sabun dan tidak ada gelembung. Simak dan bau untuk kemungkinan kebocoran

d) Konektor fleksibel tidak boleh dicat.

e) Alat pengukur tekanan dalam kondisi baik, dapat dibaca, berfungsi dan bebas kebocoran.

\section{Cargo Compressor}

a) Menggunakan detektor gas dikalibrasi untuk pengujian kebocoran. Periksa kebocoran pada semua lapisan tubuh dan batang/packing, ditambah koneksi kepipa dan selangharus dideteksi melalui teknik pengujian kebocoran.

b) Kompresor bebas karat atau kerusakan lain. Valve bebasdari korosi dan puing-puing yang akan mencegah katup dari membuka dan menutup dengan benar. Jika ditemukan rusak, katup tidak dapat diperbaiki dan harus diganti. 
c) Valve pastikan bahwa bebas dari kotoran atau sampah. Untuk larutan uji kebocoran menggunakan sabun, simak dan bau untuk kemungkinan kebocoran. Jika tidak ada gelembung berarti tidak bocor.

d) Stainless steel conector flexibel dalam kondisi kerja yang baik. Periksa kerusakan mekanis atau fisik, korosi berlebihan, retak atau menggembung. Konektor fleksibel tidak boleh dicat.

e) Untuk mesin kompresor pastikan oli tersedia. Periksa pengukur tekanan oli secara rutin selama setiap operasi kompresor. Jika minyak tekanan luar biasa tinggi atau rendah, mematikan kompresor dan memberitahu perwira jaga.

f) Cek oli pastikan levelnya minimal setengah dan tidak lebih dari $3 / 4$ pada oil glass.

g) Baut plat dasar di tempat yang benar dan mengikat kompresor

h) Kompresor benar dilumasi, pelumasan bisa bervariasi tergantung pada desain kompresor dan produsen. Periksa instruksi peralatan produsen untuk pelumas.

i) Sistem sirip pendingin. Mereka harus tetap bersih dan roda gila harus dijaga bebas dari penghalang untuk memungkinkan aliran udara yang cukup untuk pendinginan.

f) Saringan kompresor biasanya memiliki layar lebih kasar daripada saringan pompa. Namun mereka harus dibuka dan dibersihkan secara teratur untuk mencegah mereka dari yang tersumbat dan membatasi aliran ke kompresor.

g) Periksa belt, pastikan tidak terlalu kendur namun juga tidak terlalu kencang.

h) Kompresor di tempat dengan sirkulasi udara yang baik.

\section{Cargo Piping}

a) Mengecat dengan cat anti korosi. Pengecatan ini dimaksudkan untuk memberikan lapisan anti karat atau korosi pada permukaan pipa.

b) Berikutnya adalah memberikan lapisan pipa yang telah dicat dengan cat anti karat atau korosi dengan cat biasa (top coating).

c) Menghilangkan lapisan karat, diketok dengan palu, dibersihkan dengan amplas untuk menghilangkan sisa kotoran yang terdapat pada permukaan pipa, lalu dicat dengan cat anti karat dan cat biasa (top coating).

d) Adapun prosedur atau tindakan perawatan dalam pemasangan perpipaan sistem remote control di kapal adalah:

1) Beri perlindungan anti karat, hindari penimbunan aliran pada pipa.

2) Hindari terbentuknya kantongkantong udara.

3) Hindari pemasangan pipa yang panjang dan lurus untuk mencegah tegangan pada penghubung.

4) Selesai pemasangan, pipa dibersihkan dari kotoran.

5) Periksa kelonggaran sambungan.

6) Periksa lampu-lampu indikasi.

7) Periksa bahwa dudukan berada ditempat sehingga pipa tidak membungkuk atau meregangkan.

8) Pipa benar ditandai "uap" atau "cair" , atau kode warna yang sesuai.

\section{KESIMPULAN DAN SARAN}

\section{A. Kesimpulan}

Penulis dapat mengambil kesimpulan dari permasalahan yang dihadapi yang antara lain :

1. Perubahan suhu di luar kapal dapat sangat mempengaruhi kegiatan penanganan bongkar muat terutama pada saat berlangsungnya pemuatan, dimana pada saat suhu di luar sangat panas dapat mempengaruhi kondisi muatan dan tangki itu sendiri. 
Bintang Dwi Prayogo, Samsul Huda dan Tri Kismantoro

2. Penanganan permasalahan yang berhubungan dengan suhu dari luar kapal yang mempengaruhi suhu dalam tangki muat sangatlah perlu disaat melakukan proses pemuatan. Dampak yang diakibatkan/timbul karena perubahan suhu dapat diminimalkan menggunakan metode cool down dan chilling, hal ini sesuai dengan International Gas Carrier Code.

\section{B. Saran}

Penulis akan memberikan sedikit saran yang mungkin dapat berguna bagi semua pihak yang berkepentingan.

1. Lakukan perawatan yang baik dan teratur pada pressure gauge, dan pipapipa cool down untuk menjaga kondisi muatan dan tangki tetap dalam kondisi baik.

2. Lakukan prosedur yang sudah ada untuk menanggulangi jika suatu saat suhu muatan berubah.

\section{DAFTAR PUSTAKA}

Badan Diklat Perhubungan. 2000. Gas Tanker Familiarization. Jakarta

IGC Code. 1993

IMO. 1993. International Code for The Construction and Equipment of Ships Carrying Liquefied Gas In Bulk. London

ISIGNTT (International Safety Guide for Inland Navigation Tank-barges and Terminals). $1^{\text {st }}$ Edition. 2010

Martopo, Arso. 2001. Penanganan Muatan. Semarang: Politeknik Ilmu Pelayaran Semarang.

Mc Guire and White. 2000. Liquified Gas Handling Principles $3^{\text {rd }}$ Edition. London : Witherby \& Co. Ltd
OCIMF, IAPH, ISGOTT $5^{\text {th }}$ Edition. 2000. London : Witherby \& Co. Ltd

Operations and Maintenance Handbook. 2009

Wijaya, Suhendra. 2010. Liquefied Gas Tanker Specialized Training Programme. Jakarta

Sukandarumidi. 2002. Metodologi Penelitian Kualitatif

Woolcott, T.W.V. Liquefied Petroleum Gas Tanker Practice, $2^{\text {nd }}$ Edition,

World Marine Technologi LTD. 2005. Norman Lady Cargo Operating Manual

www.wisegeek.org/what-is-ambienttemperature, Mary McMahon 